\title{
Implementasi Prinsip Nilai dan Etika Pekerja Sosial dalam Penanganan Pengemis di IPSM Yogyakarta
}

\author{
Novie Purnia Putri \\ Program Pascasarjana UIN Sunan Kalijaga, Indonesia \\ novieppurniapp@gmail.com
}

\begin{abstract}
Social work is as a help profession. It has a basic task in overcoming social problems, one of them is handling the beggars. The method used in this study was a qualitative method by describing the implementation of the value principles and ethics of social workers in handling the beggars through the Yogyakarta Society of Social Workers Association and the ethical dilemmas inside. The purpose of this study was expected to provide an overview of practices in the field as an effort to improve the quality of social work, increasingly to have adequate competence, both in terms of values and ethics in carrying out their profession. The results of this study indicated that in the implementation of the value principles and ethics of social workers with reviews of acceptance, individualization, disclosure of feelings, non-judgmental attitudes, objectivity, self determination, confidentiality and accountability. The whole principles had been practiced. However, during practicing in the field, there were ethic dilemmas in the application of the principles. They were dilemmas in client confidentiality, policy laws, management care and scarce and limited resources.
\end{abstract}

Keywords: $\quad$ Ethics, Social Workers and Beggars

\begin{abstract}
Abstrak
Pekerjaan sosial sebagai profesi yang berorientasi pada pertolongan. Memiliki tugas pokok dalam mengatasi permasalahan sosial salah satunya adalah penanggulangan pengemis. Metode yang digunakan dalam penelitian ini adalah metode kualitatif dengan mendeskripsikan implementasi prinsip nilai dan etika pekerja sosial dalam penanggulangan pengemis melalui Lembaga Ikatan Pekerja Sosial Masyarakat Yogyakarta serta dilemma etis yang terdapat di dalamnya. Tujuan dari penelitian ini diharapkan memberikan gambaran praktek di lapangan sebagai upaya peningkatan kualitas pekerjaan sosial semakin memiliki kompetensi yang memadai, baik dalam segi nilai maupun etika dalam melakukan profesinya. Hasil penelitian ini menunjukkan bahwa dalam implementasi prinsip nilai dan etika pekerja sosial dengan tinjauan penerimaan, Individualisasi, Pengungkapan perasaan, sikap tidak menghakimi, objektifitas, Self Determination, kerahasian dan akutabilitas. Keseluruhan prinsip tersebut telah dipraktekkan. Namun, dalam praktek dilapangan terdapat dilemma etis dalam penerapan prinsip tersebut. Diantaranya permasalahan dalam kerahasiaan klien, undang-undang kebijakan, Management care dan Sumber daya yang langka dan terbatas
\end{abstract}

Kata Kunci: Etika, Pekerja Sosial dan Pengemis 


\section{Pendahuluan}

Indonesia merupakan negara berkembang yang memiliki permasalah kesejahteraan sosial. Menurut Badan Pusat Statistik (BPS) mencatat Indonesia mengalami titik terendah dalam hal persentase kemiskinan sejak tahun 1999, yakni sebesar 9,82 persen pada Maret 2018. Dengan persentase kemiskinan 9,82 persen, jumlah penduduk miskin atau yang pengeluaran per kapita tiap bulan di bawah garis kemiskinan mencapai 25,95 juta orang (Wahid, 2014: 11).

Kemiskinan merupakan permasalahan klasik yang menghinggapi berbagai negara dan tampaknya akan terus menjadi perosalan aktual pada masa mendatang. Kemiskinan yang terjadi karena berbagai faktor diantaranya adalah keterbatasan fisik maupun mental, rendahnya tingkat pendidikan, kurangnya keterampilan dan minimnya lapangan pekerjaan.

Salah satu dampak dari kemiskinan tersebut adalah munculnya pengemis. Pengemis menurut Peraturan Kepala Kepolisian (Perkap) Negara Republik Indonesia Tahun 2007 tentang Penanganan Pengemis pada Pasal ayat (2) sebagai orang yang mencari penghasilan dengan meminta-minta di tempat umum dengan berbagai cara dan alasan untuk mendapatkan belas kasihan orang lain. Tidak hanya pengemis tetapi orang yang mempekerjakan orang lain untuk meminta minta juga telah terdapat UU yang mengatur sebagai upaya pemerintah untuk mengurangi pengemis (Khan, 2016: 7). Pengemis yang ada di Yogyakarta disebabkan oleh budaya masyarakat yang malas bekerja dan berpendapat bahwa mengemis bisa menjadi mata pencaharian yang tidak banyak mengeluarkan tenaga dan modal (Setiawan, 2017: 43). Pengemis muncul karena kurangnya sumber daya manusia (SDM) yang lemah dan lebih senang dengan keadaan yang meminta-minta, sehingga dapat menghasilkan uang dengan gampang. Namun beberapa masyarakat juga mengatakan lapangan kerja yang sulit dengan banyaknya persyaratan 
yang membuat mereka tidak di terima di tempat kerja juga mendorong mereka untuk meminta-minta (Oktaviana, 2014: 16).

Berdasarkan faktor-faktor di atas menyebabkan permasalahpermasalahan sosial seperti pengemis yang ada di perkotaan khususnya di Kota Pariwisata Yogyakarta. Menurut Data di Dinas Sosial DIY menunjukkan, dari tahun 2013 hingga akhir September 2017 tercatat terdapat 752 pengemis yang mendapatkan assesment dari dinas terkait. Sebenarnya Pemerintah Daerah Yogyakarta sudah mengeluarkan (Perda) Nomor 1 Tahun 2014 tentang Penanggulangan Pengemis, hal ini dilakukan sebagai upaya DIY bebas dari pengemis.

Kemiskinan adalah masalah kompleks karena tidak hanya berhubungan dengan ekonomi, pendidikan, kesehatan, tetapi juga sosial, budaya dan bahkan politik. Karena itu, kemiskinan membutuhkan keseriusan penanganan yang melibatkan berbagai bidang dan pihak yang berkompeten. Dengan demikian, masalah kemiskinan membutuhkan penanganan multisektoral dengan strategi penanggulangan yang melibatkan banyak pihak dengan cara terintegrasi. Pihak pemerintahan sebagai aktor utama implementasi kebijakan perlu berinteraksi dan terhimpun dalam tiga stakeholder terkait yaitu pemerintah, masyarakat, dan swasta adalah sangat penting dalam keberhasilan implementasi kebijakan itu sendiri (Larantika dkk, 2017: 41).

Maka dari itu dibutuhkan kerja sama dari pemerintah ataupun non pemerintah untuk mengurangi gelandangan dan pengemis tersebut. Saat ini pemerintah melalui Ikatan Pekerja Sosial Masyarakat adalah salah satu lembaga sosial di DIY yang bersama-sama mengurangi tingkat pengemis melalui penanganan yang di adakan setiap minggunya, guna meminimalisir tingkat pengemis dan gelandangan yang khusunya di Yogyakarta.

Menurut Kasman dalam wawancaranya tanggal 5 November 2018 menyatakan bahwa Ikatan Pekerja Sosial Masyarakat (IPSM) 
terbentuk berdasarkan AD/ART yang awalnya bernama FK-PSM (Forum Komunikasi Pekerjaan Sosial Masyarakat) pada tanggal 8 april 1988, berdasarkan SK Walikota no. 500 tahun 2013 berganti nama yang awalnya FK-PSM menjadi IPSM dalam SK Kepala Dinsosnakertrans no. 252 tahun 2013. Di kota Yogyakarta terdapat puluhan PSM yang tersebar di seluruh wilayah dari 45 kelurahan dan 14 kecamatan. Saat ini anggota IPSM khususnya Kota Yogyakarta sudah mencapai 70 orang bekerja Full Time yaitu seorang koordinator program, seorang tenaga keuangan dan tenaga administrasi yang keseluruhannya adalah anggota PSM.

Memahami nilai dan etika merupakan persoalan penting sebagai penuntun praktik pekerjaan sosial. Nilai-nilai merupakan landasan sentral pemahaman bagi pekerja sosial didalam suatu praktik. Misal permasalahan yang sedang dihadapi klien dan mencari pertolongan cenderung berkaitan dengan adanya perbedaan nilai antara individu dan individu atau antara individu dan kelompok di dalam suatu lingkungan kehidupan mereka (Alamsyah, 2015: 97). Keyakinan tentang nilai dan etika yang benar juga berdampak pada pekerja sosial dalam mengambil suatu keputusan pada suatu perkara sehingga ketika terjadi dilema etis nilai memiliki peranan yang penting dalam membuat keputusan etik yang tepat.

\section{Permasalahan}

Fokus permasalahan dalam penelitian ini adalah bagaimana Implementasi Prisnsip Nilai Dan Etika Pekerja Sosial Dalam Penanganan Pengemis Di Ikatan Pekerja Sosial Masyarakat Yogyakarta? dan apa Saja Dilema Etis Nilai dan Etika Pekerja Sosial Dalam Penanganan Pengemis di Ikatan Pekerja Sosial Masyarakat Yogyakarta? 


\section{Pengertian Implementasi}

Implementasi merupakan tindakan atau pelaksanaan dari sebuah rencana yang sudah disusun secara matang dan terperinci, implementasi biasanya dilakukan setelah perencanaan sudah dianggap sempurna. ( Usman 2002:70). Dalam hal ini implementasi dilakukan dengan upayaupaya pemberian sarana prasarana untuk melakukan sesuatu. Dengan kata lain implementasi di lakukan dengan menggunakan aturan dan norma-norma sehingga tujuan yang telah ditetapkan berjalan dengan baik dan sesuai dengan yang di harapkan.

\section{Nilai dan Etika}

Memahami nilai dan etika merupakan persoalan penting sebagai penuntun praktek pekerjaan sosial. Nilai-nilai merupakan landasan sentral pemahaman bagi pekerja sosial didalam suatu praktik. Missal permasalahan yang sedang dihadapi klien dan mencari pertolongan cenderung berkaitan dengan adanya perbedaan nalai antara individu dan individu atau antara individu dan kelompok di dalam suatu lingkungan kehidupan mereka (Alamsyah, 2015: 97).

Kenyakinan tentang nilai yang benar juga berdampak pada pekerja sosial dalam mengambil suatu keputusan pada suatu perkara. Menurut reamera " pekerja sosial dan kesejahteraan sosial "bahwa Nilai berasal dari bahasa latin, yaitu valere yang artinya "menjadi kuat". Nilai apabila dihubungkan dengan pekerjaan sosial maka nilai yang dimaksud adalah seperangkat prinsip etik/moral yang fundamental dimana pekerja sosial harus berkomitmen dalam menjalanan prinsip pekerjaan sosial. Nilai bersifat abstrak, tentang baik atau buruk. Terdapat beberapa bentuk dilema etis dalam pekerjaan sosial (Huda, 2009: 54) yaitu: (1) Dilema etis yang terkait praktek langsung yaitu pemberian pelayanan pada individu, keluarga dan kelompok kecil. (2) Dilema etis yang terkait dengan praktek komunitas, administrasi, tindakan sosial, penelitian dan evaluasi, relasi 
dengan teman sejawat dan pendidikan professional, yaitu paling umum terjadi berkaitan dengan konflikaktual atau potensial antara aturan tugastugas pekerja sosial dalam hal-hal berikut: (a) Kerahasiaan Klien dan Komunikasi bebas. Pekerja sosial memiliki kewajiban untuk menghagai hak klien untuk kerahasiaan dan harapannya. (b) Memutuskan untuk diri sendiri dan paternalism professional. Pada kalangan pekerjaan sosial diterima bahwa biasanya klien mempunyai hak sangat mendasar untuk memutuskan suatu tindakan untuk dirinya sendiri. (c) Undangundang kebijakan dan peraturan. Pekerja sosial harus menjunjung tinggi undang-undang, kebijakan dan aturan yang relevan untuk keberfungsian organisasi pelayanan kemanusiaan dan masyarakat luas. (d) Nilainilai professional dan pribadi. pekerja sosial terkadang menemukan di lapangan bahwa nilai-nilai pribadinya bertentangan dengan nilai-nilai pekerjaan sosial atau kedudukuan resmi pimpinan lembaganya atau organisasi yang terkait. (e) Sumber daya yang langka dan terbatas. pekerja sosial dituntut membuat criteria alokasi dan mengambil keputusan dalam mengalokasiakan sumber-sumber dengan baik. (f) Management care. Pengaruh managemen care yaitu kebijakan yang dibuat untuk meningkatkan tanggung jawab fiscal dan pengendalian biaya untuk perawatan kesehatan dan pelayanan kemanusiaan. (g) Whistle-blowing (memberi peringatan). Pekerja sosial umumnya memahami kewajiban untuk melindungi klien dan public dari rekan sejawat yang tidak etis, tetapi mereka juga tahu bahwa memberi peringatan dapat memberikan dampak terhadap rekan maupun pekerja sosial yang perilaku tidak etis (Najib, 2018: 30).

Dalam melaksanakan berbagai kegiatan guna menjalankan program agar berjalan sesuia dengan tujuan dan menjadikan masyarakat sejahtera maka dari itu pekerja sosial juga mempunyai nilai dan etika dalam menjalankan tugasnya, adapun landasan nilai pekerja sosial: (1) Penerimaan, pekerja sosial yang menerima klien memperlakukan 
mereka dengan manusiawi dan secara baik, serta memberikan mereka martabat dan harga diri, dengan menumbuhkan rasa kepercayaan klien terhadap pekerja sosial melalu berbagai pendekatan, dan pekerja sosial menerima klien dengan apa adanya kondisi klien, baik fisik dan juga non- fisik yang mempunyai kekurangan. (2) Individualisasi, dalam hal ini pekerja sosial memberikan kebebasan kepada individu atas hak dan juga menghargai berbagai macam keanekaragaman klien untuk mengekspresikan kemampuan dan keuinikannya, dan juga pekerja sosial mendemonstrasikan bahwa klien memiliki hak untuk diberklakukan sebagai manusia dengan perbedaan pribadi. (3) Pengungkapan perasaan, dalam hal ini pekerja sosial mengarahkan klien untuk mnegungkapkan prasananya dengan tujuan yang di harapkan, dan pekerja sosial mengungkapkan perasaan dengan menggunakan data dan fakta dalam penyampaian informasi agar relevan. (4) Sikap tidak menghakimi, pekerja sosial tidak menghakimi klien dan menerima apapun yang di sampaikan oleh klien, sehingga klien merasa mempunyai harkat martabat yang sama. (5) Obyektifitas, tidak menilai dengan prasangkaprasangka buruk sehingga relasi dengan klien dapat terjaga dengan baik. (6) Self-Determination ( penentu nasib sendiri), klien bebas dan berhak menentukan nasib hidupnya sendiri, dengan cara bebas memilih pilihanpilihannya dan bergantung juga kepada alternative yang nantinya akan di berikan dari pekerja sosial. (7) Kerahasiaan, klien memberikan berbagai informasi dan data kepada pekerja sosial yang mana pekerja sosial harus menjaga kerahasiaan klien, sehingga tumbuhlah rasa kepercayaan antara klien dan pekerja sosial. (8) Akuntabilitas, pekerja sosial harus memiliki kemampuan yang baik dalam menangangani klien dengan metodemetode yang ada, sehingga dalam memperoleh data mendapatkan hasil yang akurat, dikarenakan pekerja sosialnya memiliki kopetensi yang berkompeten sehingga pekerja sosial bekerja sesuai dengan integritas profesi yang baik (Najib, 2018: 46-49). 


\section{Pekerja Sosial}

Pekerja sosial adalah bidang keahlian yang memiliki kewenangan untuk melaksanakan berbagai upaya guna meningkatkan kemampuan orang dalam melaksanakan fungsi-fungsi sosialnya melalui interaksi, agar orang dapat menyesuaikan diri dengan situasi kehidupannya secara memuaskan, Keikhasan pekerja sosial adalah pemahaman dan keterampilan dalam memanipulasi perilaku manusia sebagai makhluk sosial. Pekerjaan sosial adalah ilmu terapan yang memiliki tujuan untuk perubahan atau menghasilkan tindakan, bukan sekedar untuk memahami fenomena sosial (Barsky, 2010: 23). Dalam hal ini pekerja sosial menjadi pekerja yang mempunyai kualifikasi yang mumpuni sehingga menjadikan tenaga professional yang tidak hanya bidang akademisi tetapi dilapangan juga bisa menjalankan tugas dan fungsinya dengan baik (Taftazani, 2014:7). Pekerja sosial dilatih untuk menegakkan dan serangkaian nilainilai terkemuka yang berfokus pada kesetaraan sosial, hak kesejahteraan, hak asasi manusia, diskriminasi, dan penindasan (Derek, 2015: 16).

Pekerja sosial dipandang sebagai sebuah bidang keahlian (profesi), yang berarti memiliki landasan keilmuan dan seni dalam praktik (dicirikan dengan penyelenggaraan pendidikan tinggi), sehingga muncul juga definisi pekerja sosial sebagai profesi yang memiliki peranan paling penting dalam domain pembangunan kesejahteraan sosial. Sebagai suatu profesi kemanusiaan, pekerjaan sosial memiliki paradigma yang memandang bahwa usaha kesejahteraan sosial merupakan institusi strategis bagi keberhasilan pembangunan (https://id.wikipedia.org/ wiki/Pekerja_sosial). Pekerja social juga disebut, sebuah profesi yang mendorong perubahan sosial, memecahkan masalah dalam kaitannya.

\section{Pengemis}

Pengemis pada Pasal ayat (1) merupakan tempat tinggal layak, pekerjaan tetap, dan hidup berpindah pindah dari satu tempat ke tempat 
lain yang tidak sepantasnya menurut aturan dan norma kehidupan masyarakat. Sedangkan pengemis dijelaskan pada ayat (2) sebagai orang yang mencari penghasilan dengan meminta-minta di tempat umum dengan berbagai cara dan alasan untuk mendapatkan belas kasihan orang lain. Pengemis juga di sebut orang-orang yang mencari nafkah dengan meminta-minta di depan umum dengan berbagai cara dan alasan untuk mendapat perhatian dan mengharapkan belas kasihan dari orang lain (Kementrian Sosial RI, 2008: 126).

Pengemis dibagi menjadi dua golongan, yaitu Pengemis Murni dan Pengemis Tidak Murni, Pengemis Murni adalah mereka yang mempunyai tempat tinggal tertentu yang penghidupan seluruhnya atas dasar meminta-minta pada waktu tertentu. Sedangkan Pengemis Tidak Murni adalah mereka yang mempunyai tempat tinggal yang sebagian penghasilannya diperoleh dari meminta-minta pada waktu tertentu. Adanya pengemis dikarenakan dua faktor, yaitu: (1) Faktor eksternal, antara lain: gagal dalam mendapatkan pekerjaan,terdesak oleh keadaan seperti tertimpa bencana alam dan perang, pengaruh orang lain. (2) Faktor internal, antara lain: kurangnya bekal pendidikan dan ketrampilan, rasa renda diri atau kurang percaya diri, kurang sikap untuk hidup dikota besar, sakit jiwa atau cacat tubuh (Effendi, 1993: 114).

\section{Metode Penelitian}

Jenis penelitian yang digunakan dalam penelitian ini adalah deskriptif dengan menggunakan pendekatan kualitatif. Penelitian deskriptif adalah penelitian yang bertujuan menggambarkan secara tepat sifat-sifat suatu individu, keadaan, gejala, atau kelompok tertentu, atau untuk melakukan penyebaran suatu gejala, atau untuk menentukan ada tidaknya hubungan antara suatu gejala dengan gejala lain dalam masyarakat metode penelitian kualitatif sering disebut metode penelitian 
naturalistik karena penelitiannya dilakukan pada kondisi yang alamiah (natural setting ) (Sugiono, 2019:94). Penelitian deskriptif ditujukan untuk mendeskripsikan suatu keadaan atau fenomena-fenomena apa adanya (Sukamdinata, 2010:18).

Penelitian kualitatif lebih menekankan analisisnya pada proses penyimpulan deduktif dan induktif serta pada analisis terhadap dinamika hubungan antar fenomena yang diamati, dengan menggunakan logika ilmiah (Saifuddin, 2011: 1) ' Lokasi dan waktu Penelitian dilakukan di Ikatan Pekerja Sosial Masyarakat Yogyakarta. Informan Penelitian berupa Ketua serta staf IPSM dan pengemis di Yogyakarta. Teknik Pengumpulan data menggunakan observasi yaitu teknik yang menuntut adanya pengamatan dari peneliti baik secara langsung maupun tidak langsung terhadap objek penelitian (Noor, 2016: 40) Wawancara atau interview adalah suatu cara pengumpulan data yang digunakan untuk memperoleh informasi langsung dari sumbernya (Meilia, 2010: 19 ). Dokumentasi adalah catatan peristiwa yang sudah berlalu, dokumen bisa berbentuk tulisan, gambar, atau karya-karya monumental dari seseorang (Sugiono, 2019:82).

\section{Implementasi Nilai dan Etika Pekerja Sosial dalam Penanganan Pengemis di IPSM Yogyakarta}

Salah satu upaya Ikatan Pekerja Sosial Masyarakat (IPSM) Yogyakarta yang turut andil dalam penjangkauan pengemis menggunakan landasan nilai-dan etika pekerja sosial. Adapun landasan nilai dan etika pekerja sosial dalam penanganan pengemis berupa : (1) Penerimaan, dalam tahap penerimaan IPSM melakukan pendekatan terhadap klien dengan cara menanyakan data diri, namun disini IPSM menyesuaikan diri kepada klien yang ditemui, seperti halnya menemukan pengemis bapak Endang Lili Sadhewi yang beralamat di Ciamis. IPSM bertanya dengan menggunakan bahasa yang bisa dipahami oleh klien guna menciptakan 
komunasi yang interaktif. Seperti contohnya IPSM bertemu dengan bapak Endang yang berasal dari Ciamis, saat melakukan pencariian data diri pengemis tersebutmaka pekerja sosial menggunakan bahasa Jawa.

Pekerja sosial IPSM juga menerima bapak Endang dilihat dari pekerja sosial yang tidak memberikan jarak antara pengemis dengan pekerja sosial, berbaur dan bercerita santai layaknya kawan dan tidak ada pembatas. IPSM juga terjun kelapangan dalam penjangkauan tidak menggunakan atribut atau identitas sebagai pekerja sosial sehingga pengemis juga tidak merasa terganggu dan takut. (2) Individualisasi, IPSM selalu menjadikan klien untuk menjadi dirinya sendiri dan menunjukkan bagaimana keadaanya dengan berbagai cara. Namun IPSM tak jarang menjumpai pengemis yang berkali-kali berbohong dalam penyampaian data dirinya, sehingga menjadikan IPSM sulit untuk mendata.

IPSM tetap melakukan dialog terus menerus dengan berbagai pendekatan sehingga klien bisa dan mau menunjukkan data diri aslinya, dan dalam pendampingan IPSM juga memberikan hak individu kepada klien untuk memilih keterampilan apa yang akan nantinya diikuti oleh pengemis yang akan mendapatkan penanganan. (3) Pengungkapan perasaan. Pengemis yang dijumpai oleh IPSM tidak semuanya bertubuh normal seperti ibu Sri yang ditemui di jalan maliboro sedang memintaminta dengan tubuh rentannya dan rambut putih. IPSM dalam hal penjangkauan tidak memilih-milih, walaupun ibu Sri sudah berusia lanjut, IPSM menghargai Ibu Sri yang selalu banyak bercerita dan melayani klien, mendengarkan keluh kesahnya.

Dalam hal ini pekerja sosial memberikan kebebasan kepada ibu Sri untuk mengungkapkan semua keluh kesahnya. (4) Sikap tidak menghakimi, walaupun sering dijumpai pengemis yang berbohong akan data dirinya pekerja sosial tetap terus sabar dan tidak menghakimi pengemis yang ditanyai tidak memberikan jawaban pasti dan bahkan berbohong bahwa tidak memiliki data diri (KTP). Seperti bapak Slamet 
yang dijumpai di depan Mirota Kampus Swalayan, ketika ditanya Bapak tersebut tidak mengaku alamatnya berasal dari mana. Akan tetapi IPSM berkali-kali dengan sabar dan menemui bapak Slamet dan akhirnya bapak tersebut memberitahukan bahwa ia berasal dari Semarang. (5) Obyektifitas, perlunya tidak menerka-nerka dan berprasangka buruk terhadap klien sangat dibutuhkan. Sama halnya di IPSM mereka selalu bersifat objektif dan berbicara dengan data kepada klien sehingga terjalin hubungan saling percaya dan dalam penyampaian pemberian pelatihan IPSM melihatkan kepada pengemis berupa foto kegiatan yang nantinyan akan dilakukan apabila pengemis tersebut bersedia untuk dibina. (6) Self-Determination ( penentu nasib sendiri), Penanggulangan pada pengemis dilakukan dengan pemberian keterampilan dan keahlian yang diminati oleh pengemis. Supaya pengemis yang diberikan keterampilan bersedian mengikuti berbagai rangkaian pembinaan yang diberikan (Rina Rohmaniyati, 2016: 5).

Pengemis dibebaskan untuk memilih pelatihan apa yang nantinya akan dilakukan. Upaya pelatihan tersebut nantinya pengemis akan di entaskan dari jalanan atau dikembalikan ke daerah asalnya. Contoh Bapak Tono yang meminta pelatihan bengkel motor, dan di berikan pelatihan selama 6 bulan sehingga bisa kembali lagi ke daerah asalnya di Tuban untuk membuka bengkel. (7) Kerahasiaan, ditemui di Lapangan pekerja sosial IPSM belum bisa menjaga privasi klien. Upaya pengambilan foto ketika penjangkauan dengan tujuan sebagai syarat arsip dokumentasi ternyata sering di unggah ke sosial Media. (8) Akuntabilitas, pekerja sosial yang ada di IPSM mempunyai tenaga professional yang mengetahui metode dan pendekatan apasaja yang akan dipakai dilapangan untuk mendekatkan diri kepada pengemis yang ada di lapangan, sehingga data yang di dapat juga akurat dan pengemis juga mau untuk di data dikarenakan pendekatan penanganan yang benar. 


\section{Dilema etis dalam Implementasi Nilai dan Etika Pekerjaan Sosial dalam Penanganan Pengemis Di Ikatan Pekerja Sosial Yogyakarta}

Terdapat 70 pekerja sosial yang berusia 45-70 tahun. Mereka merupakan perwakilan dari masing -masing kecamantan di Yogyakarta. Dalam praktek di lapangan pekerja sosial di Ikatan Pekerja Sosial Masyarakat Yogyakarta sudah mencoba untuk menerapkan prinsip nilai dan etika sesuai dengan kode etik pekerja sosial. Akan tetapi tidak bisa dipungkiri terdapat beberapa dilema etis yang terjadi dilapangan diantaranya yaitu : (1) Kerahasiaan Klien dan Komunikasi bebas; Pekerja sosial yang kurang memahami tentang privasi klien, ketika di lapangan pekerja sosial diperbolehkan untuk mengambil gambar klien dengan tujuan sebagai pelengkap data administrasi. Akan tetapi tidak jarang para pekerja sosial tersebutmenyebarluaskan gambar tersebut ke ranah publik tanpa menggunakan inisial dan bahkan menceritakan permasalahan yang dialami klien kepada orang lain. (2) Memutuskan untuk diri sendiri dan paternalism professional; Dilema etis muncul ketika pekerja sosial mencoba mengarahkan pengemis dalam pengambilan keputusan (Edward, 2015: 88) yang bertujuan membantunya pengemis dalam mengembangkan keterampilan yang diperlukan. Akan tetapi apanila pengemis tidak bersedia untuk diarahkan dalam mengikuti pelatihanpelatihan keterampilan yang bertujuan untuk meningkatkan softskill. Mereka lebih memilih untuk tetap menjadi pengemis maka pekerja sosial tidak bisa lagi memaksakan kehendak kepada klien. (3) Undang-undang kebijakan dan peraturan; ketika pekerja sosial melakukan penjangkauan tidak jarang pekerja sosial memberikan uang terlebih dahulu dengan tujuan dapat menggali informasi menganai klien tersebut. Padahal sudah dikeluarkan Peraturan Daerah Yogyakarta No 1 Tahun 2014 tentang penaganan gelandangan dan pengemis disebut sebagai pihak baik individu, lembaga atau badan hukum dilarang memeberikan uang atau barang dalam bentukapapun kepada pengemis dan gelandangan ditempat 
umum. Jika ketentuan dilanggar sanksi pidana kurungan maksimal 10 hari atau benda maksimal Rp 1 Juta. Kurangnya sinergitas antara Dinas Sosial dengan Satuan Pamong Praja. Hal ini terjadi ketika pekerja sosial melakukan engegment dilapangan bersamaan dengan Satuan Pamong Praja. Satuan Pamong Praja cenderung melakukan tindakan langsung yakni dengan cara melakukan penangkapan secara paksa terhadap pengemis tersebut. (4) Management care; kurangnya management care dalam Kelompok Pekerja Sosial. Dalam pelaksaan Evaluasi oleh IPSM dilakukan sebulan sebanyak satu kali untuk mengetahui dan pembahasan tentang permasalahan yang dihadapi oleh klien. Dengan cakupan wilayah yang terdiri dari tiga bagian yaitu Selatan, Utara dan Tengah. Masingmasing wilayah Yogyakarta memiliki Koordinator masing-masing akan tetapi dalam pelaksanaan jangkaun dilapangan masih terdapat tumpang-tindih dalam pembagian tugas. (5) Sumber daya yang langka dan terbatas; Faktor Usia pekerja sosial yang tidak Produktif menjadi salah satu kendala didalam IPSM. Mayoritas pekerja sosial yang sudah berusia pensiun dan ibu-ibu rumah tangga yang menjadi angggota dan sangatlah sedikit generasi muda yang ikut dalam lembaga ini. Sehingga berdampak pada sumber daya manusia yang langka dan terbatas yang sesuai dengan bidang professional. Apalagi kebanyakan pekerja sosial bukan berasal dari lulusan Pekerjaan sosial dll. Hal ini disebabkan karena kurangnya publikasi dari pihak-pihak kecamatan, kelurahan, serta RW ke masyarakat luas.

\section{Simpulan}

Dari Uraian di atas, maka dapat disimpukan bahwa Implementasi prinsip nilai dan etika dalam pekerjaan sosial pada pekerja sosial di IPSM Yogyakarta menerapkan beberapa prinsip etik diantaranya: penerimaan, Individualisasi, Pengungkapan perasaan, sikap tidak menghakimi, objek- 
tifitas, Self Determination, kerahasian dan akutabilitas. Akan tetapi dalam penerapannya terdapat hal-hal yang tidak sesuai. Seperti pekerja sosial yang kurang memahami pentingnya menjaga kerahasiaan klien terhadap orang lain. Sedangakan dalam dilemma etisnya adalah pekerja sosial yang melanggar Undang-undang serta Kurangnya sinergitas antara Dinas Sosial dan Kurangnya management care dalam Kelompok Pekerja Sosial.

\section{Daftar Pustaka}

Barsky, Allan Edward. 2010. Ethics and Values in Sosial Work: An Integrated Approaceh for a Comprehensive Curriculum. New York: Oxford University Press.

Braverly Edwards, dan Rejoice Addea, Ethical Decision-Making Models in Resolving Ethical Dilemmas in Rural Practice: Implications for Social Work Practice and Education, journal of Social Work Values and Ethict, vol 12, no. 1. 2015

Chechak, Derek. Sosial Work as a Value-Based Profession: Value Conflicts and Implication for Pravtitioners'Self- Conceptss. 2015, Jourrnal of Social Work Value and Ethics, vol 12, no 2, 2015

Huda, Miftahul. 2009. Pekerjaan Sosial dan Kesejahteraan Sosial Sebuah Pengantar. Yogyakarta: Pustaka Pelajar.

Juliansyah, Noor. 2016. Metodologi Penelitian Skripsi, Tesis, Disertasi, dan Karya Ilmiah. Jakarta: Kencana Prenada Media Group.

Khan MM, MK Hossain, N Hasina, S Uddin dan M Furdaose, Status and Sicial Evaluation towards Beggars in Bangladesh: Context of Sykhet City. Internasional Journal of Sosial Science Studie, Vol 4, No .6, Juni 2016

Larantika A.A.A.D, Zauhar S, Makmur M \& setyowati E. Collaboration As A Strategy For Poverty Alleviation. International Journal of Social Sciences and Humanities. vol.1 no.3, Desember 2017 
Meilia, Nur Indah. 2010. Statistik Deskriptif dan Induktif. Yogyakarta: Graha Ilmu.

Najib, Abdul. 2018. Integrasi Kesejahteraan Sosial dan Pekerjaa Sosial,. Yogyakarta: Samudra Biru.

Oktaviana. Maulida. Pengemis Dan Upaya Penanggulangannya (Studi Kasus Di Desa Rarang Tengah Kecamatan Terara Kabupaten Lombok Timur). Jurnal Pendidikan Ekonomi UNDIKSHA, vol: 4 no: 1, 2014.

Putu. Indra Setiawan . 2017, Determinasi Keberadaan Pengemis Perkotaan Di Kecamatan Denpasar Barat, Jurnal Ilmu Sosial Dan Humaniora, vol. 6 no.1, 2014.

Roberts, Albert R. dan Gilbert J. Greene. 2009. Buku Pintar Pekerja Sosial (Social Workers' Desk Reference). Jakarta: PT. BPK Gunung Mulia. Rohmaniyati, Rina. Pemberdayaan Gelandangan Dan Pengemis (Gepeng) Melalui Usaha Ekonomi Produktif. Jurnal Pendidikan Luar Sekolah Di Lembaga Sosial Hafara, vol. 5 no. 2, 2016.

Saifuddin. Azwar Ma .2011. Metode Penelitian. Yogyakarta: Pustaka Pelajar. Sugiono. 2015. Memahami Penelitian Kualitatif. Bandung: Alfabeta.

Suharto, Edi Dkk. 2011. Pekerjaan Sosial di Indonesia; Sejarah dan Dinamika Perkembangan. Yogyakarta: Samudra Biru.

Syah, Cepi Yusrun Alam. 2015. Praktik Pekerjaan Sosial Suatu Tuntutan Intervensi, Yogyakarta: Pustaka Pelajar.

Sukamdinata, Nana Syaodih. 2010. Metode Penelitian Pendidikan. Bandung: Pt Remaja Rosdakarya.

Taftazani., Muhammad Budi. Teori Pekerjaan Sosial Dalam Lintasan Modernisme Dan Posmodernisme . Journal Social Work. vol. 4. no. 2, 2014.

Wahid, Nusron. 2014. Keuangan Inlusif Membongkar Hegemoni Keuangan. Jakarta: Kepustakaan Populer Gramedia

\section{Sumber Internet}

http://kompasiana.com/septianavinaangraini/mengapa-pekerja-sosialkurang-diminati-oleh-generasi-muda. 